\title{
The effects of body mass index, smoking and anemia on fetal birth weight
}

\author{
Ersin Çintesun $^{1}$ (D), Feyza Nur İncesu Çintesun ${ }^{2}$ (D) , Meltem Aydoğdu ${ }^{1}$ (D), Emine Taşkın ${ }^{1}$ \\ Mete Can Ateş ${ }^{1}$ (D) , Abdul Hamid Güler ${ }^{1}$ (D) , Çetin Çelik ${ }^{1}$ \\ ${ }^{1}$ Department of Obstetrics \& Gynecology, Faculty of Medicine, Selçuk University, Konya, Turkey \\ ${ }^{2}$ Clinics of Obstetrics \& Gynecology, Konya City Hospital, Health Sciences University, Konya, Turkey
}

\begin{abstract}
Objective: Fetal growth is an important indicator of fetal health. Low birth weight $(\mathrm{LBW})$ is also associated with increased perinatal morbidity and mortality. Numerous factors that affect fetal weight have been identified. In this study, we aimed to investigate the effect of body mass index, smoking, and anemia on fetal birth weight on term pregnant women who had vaginal delivery in our clinic.

Methods: This study is a retrospective cross-sectional study. This study included patients who had a spontaneous vaginal delivery at our hospital between January 1st, 2018, and June 15th, 2020. Measurements of hemoglobin $(\mathrm{Hb})$ and hematocrit (Hct) levels during birth supported the diagnosis of anemia. Hb levels were compared in three categories in this study: (1) $\mathrm{Hb}<10 \mathrm{~g} / \mathrm{dL}$; (2) $\geq 10<11$ $\mathrm{g} / \mathrm{dL}$; and (3) $\mathrm{Hb} \geq 11 \mathrm{~g} / \mathrm{dL}$. Anemia was defined as having a $\mathrm{Hb}$ level $<11 \mathrm{mg} / \mathrm{dL}$. Birth weight was categorized as LBW $<2500 \mathrm{~g}$; normal birth weight (NBW) as $\geq 2500-3999 \mathrm{~g}$, and macrosomia as $\geq 4000 \mathrm{~g}$.

Results: Analysis was performed on 1428 pregnant women. There was a statistically significant difference for the Hct and $\mathrm{Hb}$ subgroups between the groups $(\mathrm{p}<0.05)$. Fetal birth weight was found higher in the non-smoking group than in the smoking group $(3302.1 \pm 381.5 \mathrm{~g}$ vs. $2839.7 \pm 491.5 \mathrm{~g} ; \mathrm{p}<0.001)$. Body mass index (BMI) and $\mathrm{Hb}$ levels positively predicted fetal birth weight $(\beta=0.134$; $\mathrm{p}<0.001$ and $\beta=0.051 ; \mathrm{p}=0.046)$, smoking was negatively predicted fetal birth weight $(\beta=-0.245 ; \mathrm{p}<0.001)$.

Conclusion: BMI, Hb levels, and smoking status during mothers' delivery are effective on fetal weight. Smoking was the strongest predictor of fetal birth weight compared with the other variables.
\end{abstract}

Keywords: Delivery, hematocrit, hemoglobin, pregnancy, smoking.
Özet: Vücut kitle indeksi, sigara kullanımı ve aneminin fetal doğum ağırlığı üzerindeki etkisi

Amaç: Fetal büyüme, fetal sağlığın önemli bir göstergesidir. Düşük doğum ağırlığı (DDA), artmış perinatal morbidite ve mortalite ile de ilişkilendirilmektedir. Birçok faktörün fetal ağırlığı etkilediği tespit edilmiştir. Bu çalışmada, kliniğimizde vajinal doğum yapan term gebelerde vücut kitle indeksi, sigara kullanımı ve aneminin fetal doğum ağırlı̆̆ı üzerindeki etkilerini araştırmayı amaçladik.

Yöntem: Çalışmamız retrospektif kesitsel bir çalışmadır. Çalışmaya, 1 Ocak 2018 ile 15 Haziran 2020 tarihleri arasında hastanemizde spontan vajinal doğum yapan hastalar dahil edildi. Doğum esnasında hemoglobin $(\mathrm{Hb})$ ve hematokrit $(\mathrm{Hct})$ seviyelerinin ölçümü anemi tanısını destekledi. Çalışmada Hb seviyeleri üç kategoride karşılaştırıldı: (1) $\mathrm{Hb}<10 \mathrm{~g} / \mathrm{dL}$; (2) $\geq 10<11 \mathrm{~g} / \mathrm{dL}$; ve (3) $\mathrm{Hb} \geq 11 \mathrm{~g} / \mathrm{dL}$. Anemi, $\mathrm{Hb}$ seviyesinin $<11 \mathrm{mg} / \mathrm{dL}$ olması şeklinde tanımlandı. Doğum ağırlığ1 ise DDA <2500 g, normal doğum ağırlığ1 (NDA) $\geq 2500-3999$ g ve makrozomi $\geq 4000$ g olarak sinıflandırıldı.

Bulgular: Analiz 1428 gebe üzerinde gerçekleştirildi. Hct ve $\mathrm{Hb}$ alt grupları arasında istatistiksel olarak anlamlı bir fark mevcuttu $(\mathrm{p}<0.05)$. Fetal doğum ağırlığı, sigara içen gruba kıyasla sigara içmeyen grupta daha yüksek bulundu $(3302.1 \pm 381.5$ g'a karşı $2839.7 \pm 491.5 \mathrm{~g} ; \mathrm{p}<0.001)$. Vücut kitle indeksi (VKİ) ve Hb seviyeleri fetal doğum ağırlığını pozitif olarak tahmin ederken $(\beta=0.134$; $\mathrm{p}<0.001$ ve $\beta=0.051 ; \mathrm{p}=0.046$ ), sigara kullanımını fetal doğum ağırlığını negatif olarak tahmin etti $(\beta=-0.245 ; \mathrm{p}<0.001)$.

Sonuç: Annelerin doğum esnasındaki VKİ değeri, Hb seviyeleri ve sigara kullanımı fetal ağırlık üzerinde etkilidir. Sigara kullanımı, diğer değişkenlerle kıyaslandığında fetal doğum ağırlığının en güçlü prediktörüdür.

Anahtar sözcükler: Doğum, hematokrit, hemoglobin, gebelik, sigara kullanımı.

Correspondence: Ersin Çintesun, MD. Department of Obstetrics \& Gynecology, Faculty of Medicine, Selçuk University, Konya, Turkey. e-mail: ersincintesun@gmail.com / Received: April 9, 2021; Accepted: June 21, 2021

How to cite this article: Çintesun E, İncesu Çintesun FN, Aydoğdu M, Taşkın E, Ateş MC, Güler AH, Çelik Ç. The effects of body mass index, smoking and anemia on fetal birth weight. Perinatal Journal 2021;29(2):106-112. doi:10.2399/prn.21.0292004 


\section{Introduction}

Fetal growth is an important indicator of fetal health. Low birth weight (LBW) is also associated with increased perinatal morbidity and mortality. ${ }^{[1]}$ Fetal growth is mostly modulated by placental functions. Numerous factors have been identified that affect fetal growth and weight gain. ${ }^{[2]}$ These are maternal weight before pregnancy, weight gain during pregnancy, maternal nutrition (anemia), harmful habits of the mother (e.g. smoking, alcohol, caffeine, cocaine, opiates), drugs used by the mother during pregnancy, mother's stress and anxiety, mother's perinatal infections, mother's pregnancy or chronic diseases (e.g. preeclampsia, diabetes, autoimmune diseases), and the mother's condition of exercise. $^{[2-4]}$

Cigarette smoking is one of the most important risk factors associated with adverse maternal, fetal, and neonatal outcomes. ${ }^{[5]}$ As a result of increased public health education, smoking rates have tended to decrease compared with previous years. ${ }^{[6]}$ However, some women continue to smoke during pregnancy. A study in the United States of America (USA) showed that $8 \%$ of pregnant women smoked at any time during pregnancy. ${ }^{[7]}$ The rate of smoking during pregnancy in studies in Turkey ranged from $2-17 \%{ }^{[8]}$ It is difficult to get the true prevalence of smoking during pregnancy due to incomplete records and self-reported systems. Studies based on biochemical markers such as exhaled carbon monoxide and urinary cotinine have indicated that pregnant women underreport both smoking status and the extent of smoking. ${ }^{[9]}$ Secondhand smoke in pregnancy is also one of the important causes of the elevation of cotinine levels in the blood. Many adverse effects of smoking on pregnancy have been reported. In a study conducted in the USA, 5 to $8 \%$ of preterm births, 13 to $19 \%$ of term infants with intrauterine growth restriction, 5 to $7 \%$ of preterm-related deaths, and 23 to $34 \%$ of sudden infant death syndrome were found to be related to prenatal smoking. ${ }^{[10]}$

Anemia is a leading global health problem affecting millions of women of reproductive age. ${ }^{[1]]}$ Anemia during pregnancy is a fundamental indicator of maternal mortality and poor birth outcomes in both developing and developed countries. ${ }^{[4]}$ Many studies showed that low maternal hemoglobin $(\mathrm{Hb})(<110 \mathrm{~g} / \mathrm{L})$ was associated with poor birth outcomes (LBW, preterm birth, small for gestational age (SGA), stillbirth, and perinatal and neonatal mortality) and adverse maternal outcomes (postpartum hemorrhage, preeclampsia, and blood transfusion). ${ }^{[3,4,12]}$

When the literature is reviewed, it will be seen that many factors are affecting fetal birth weight. Obesity, anemia, and smoking are the most important public health factors of our century. However, although these three variables have been shown in the literature to be separately effective on fetal birth weight, it is known that they are also effective on each other. ${ }^{[13]}$ It has also been shown that anemic women have higher umbilical cord oxygen levels. ${ }^{[14]}$ For this reason, this study aimed to examine the relationships of these variables with each other separately and examine the effects of these variables on fetal birth weight by correcting the confounding effect.

This study aimed to investigate the effect of body mass index, smoking, and anemia on fetal birth weight on term pregnant women who had a vaginal delivery in our clinic.

\section{Methods}

\section{Study design}

This study was a retrospective cross-sectional study. This study included patients who had a spontaneous vaginal delivery at Selçuk University Medical Faculty Hospital between January 1st, 2018, and June 15th, 2020. The Local ethics committee of Selçuk University approved the study.

\section{Inclusion and exclusion criteria}

The inclusion criteria were as follows: being at 37 weeks of gestation and later and spontaneous vaginal delivery. The exclusion criteria were as follows: induced or spontaneous preterm deliveries, maternal systemic diseases (e.g. preeclampsia, hypertension, diabetes), uterine and fetal anomalies, cesarean deliveries (Fig. 1).

\section{Birth outcomes and maternal variables}

The gestational week was calculated according to the women's last menstrual period or ultrasound results in the first trimester. The measurement of $\mathrm{Hb}$ and hematocrit (Hct) levels during birth supported the diagnosis of anemia. $\mathrm{Hb}$ levels were compared in three categories in this study: (1) $\mathrm{Hb}<10 \mathrm{~g} / \mathrm{dL},(2) \geq 10<11 \mathrm{~g} / \mathrm{dL}$, (3) $\mathrm{Hb} \geq 11$ $\mathrm{g} / \mathrm{dL}$. Anemia was defined as having a $\mathrm{Hb}$ level $<11$ $\mathrm{mg} / \mathrm{dL}$. The birth weight was categorized as $\mathrm{LBW}<2500$ g, normal birth weight $(\mathrm{NBW}) \geq 2500-3999 \mathrm{~g}$, and 
macrosomia $\geq 4000 \mathrm{~g}$. Hemogram and hematocrit values of the patients were blood results before birth. Body mass index (BMI) was accepted as the pre-birth measurements.

\section{Statistical analysis}

Statistical analysis was performed using the Statistical Package for the Social Sciences (SPSS) version 21.0 software (IBM Corp., Armonk, NY, USA). The distribution of variables was tested for normality using histograms and the Shapiro-Wilk test. Outliers were analyzed using boxplot graphics. Parametric continuous data are presented as mean \pm standard deviation, nonparametric continuous data are presented as median (min-max), and categorical variables are expressed as number (percentage). Data were analyzed using Student's t-test, the Mann-Whitney $U$ test, one-way analysis of variance (ANOVA), the Kruskal-Wallis test, and Pearson's chisquare test, where appropriate. Multivariate linear regression analysis was used to predict fetal birth weight using age, smoking, BMI, and $\mathrm{Hb}$ levels. A p-value <.05 was considered statistically significant.

\section{Results}

There were a total of 4137 total deliveries at our tertiary hospital between January 1st, 2018, and June 15th, 2020. Of these, 2141 women who underwent cesarean delivery were excluded from the study. The delivery records of 1996 patients who had vaginal delivery were analyzed. Of these, 34 patients were excluded from the study because of fetal problems (fetal anomaly, intrauterine fetal death, etc.) and 534 patients because of maternal problems (preeclampsia, gestational diabetes mellitus, fetal growth restriction, etc.). As a result, a total of 1428 patients' records were included in this study (Fig. 1).

Analysis was performed on 1428 pregnant women. 72 (5\%) of these patients reported smoking, and 1356 (95\%) pregnant women reported not smoking. Gravida and parity were higher in the smoking group than in the nonsmoking group [3(1-6) vs $2(1-8), \mathrm{p}=0.001$ and $1(0-4)$ vs $1(0-7), p=0.009]$. Hct and $\mathrm{Hb}$ levels were statistically different between groups $(\mathrm{p}=0.026)$. Fetal birth weight was lower in the smoking group $(2839.7 \pm 491.5$ vs $3302.1 \pm$ 381.5 , $\mathrm{p}<0.001)$. LBW was most common in the smoking group than in the non-smoking group ( $25 \%$ vs $1.2 \%$, $\mathrm{p}<0.001)($ Table 1).

The comparison of variables according to fetal birth weight categories is summarized in Table 2. Patients

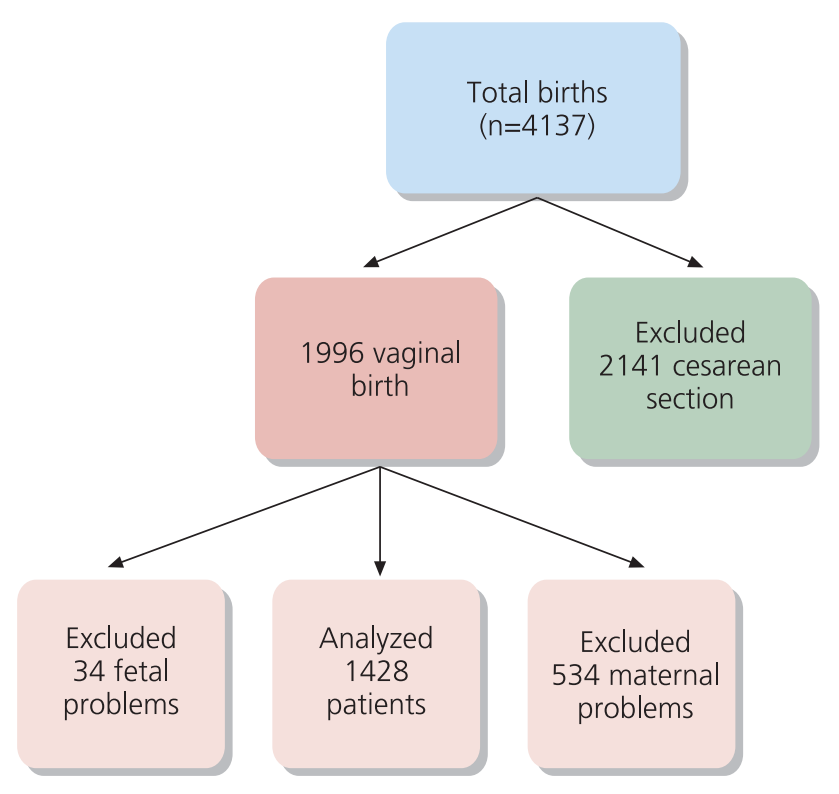

Fig. 1. Flow diagram.

were divided into three groups, as explained before (LBW, NBW, and macrosomia). When analyzing LBW and NBW + macrosomia, all variables except smoking status and $\mathrm{Hb}$ levels were similar between the groups. In the analyses among the three groups, all variables except maternal weight, BMI, and smoking status were similar between the groups. The BMI of the macrosomia group was significantly higher than in the NBW group (mean $29.7 \pm 3.6$ versus $28.5 \pm 3.3 \mathrm{~kg} / \mathrm{m}^{2} ; \mathrm{p}=0.045$ ). The smoking rate in the LBW group was also significantly higher than in the NBW and macrosomia groups (52.9\% vs $4 \%$ and $1.9 \%, \mathrm{p}<0.001$ ) (Table 2).

Multivariate linear regression analysis was performed to predict fetal birth weight using age, BMI, smoking, and $\mathrm{Hb}$ level variables. Age, BMI, smoking, and $\mathrm{Hb}$ levels were statistically significant predictors of

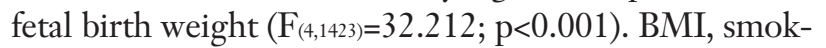
ing, and $\mathrm{Hb}$ levels separately predict fetal birth weight. While BMI and $\mathrm{Hb}$ levels positively predicted fetal birth weight $(\beta=0.134 ; p<0.001$ and $\beta=0.051 ; p=0.046)$, smoking was negatively predicted fetal birth weight $(\beta=-$ $0.245 ; \mathrm{p}<0.001)$. Smoking was the strongest predictor of fetal birth weight compared with the other variables. Equation predicting fetal weight: $\mathrm{B}=2707.137$ $2.167^{*}$ Age +16.227 * BMI -444.679 * Smoking (yes $=1$. no $=0)+15.469 * \mathrm{Hb}($ Table 3). 


\section{Discussion}

In this study, maternal BMI, anemia, and smoking history, which affect fetal birth weight, were investigated. It was found that fetal birth weight was lower in smokers. In addition, we found the Hct value to be lower in smokers. In the study, multivariate regression analysis was performed to eliminate possible confounding effects of variables on each other. As a result of this analysis, it was found that smoking, $\mathrm{Hb}$, and BMI values had a significant effect on fetal weight. Smoking was found to be the most effective variable.

We found that the anemia rate was significantly lower in the LBW group and patients who smoked. Anemia in pregnancy is a global health problem as the World Health Organization (WHO) has declared. ${ }^{[15]}$ Some degree of dilutional anemia may be seen in normal pregnancy physiology, but iron deficiency anemia can have severe adverse health problems for both the mother and child. ${ }^{[16]}$ Due to dilutional anemia, the anemia limits of pregnant women and healthy women are different. The classification recommended by the American College of Obstetricians and Gynecologists (ACOG) for anemia is as follows: In the first trimester, $\mathrm{Hb}(\mathrm{g} / \mathrm{dL})$ and Hct (\%) levels below $11 \mathrm{~g} / \mathrm{dL}$ and $33 \%$, respectively; in the second trimester $10.5 \mathrm{~g} / \mathrm{dL}$ and $32 \%$, respectively; and in the third trimester $11 \mathrm{~g} / \mathrm{dL}$ and $33 \%$, respectively. ${ }^{[17]}$ There are many large studies on fetal and maternal negative effects of severe anemia during pregnancy. ${ }^{[18,19]}$ A study by Zamora et al. found that severe antenatal or postnatal maternal anemia (of any type) was associated with an increased risk of maternal death $(\mathrm{OR}=2.36){ }^{[18]}$ Tunkyi et al. found that prematurity, birth weight, and hypertensive disorders of pregnancy were different between the anemic and non-anemic pregnancies. ${ }^{[19]}$ In our study, we did not investigate maternal outcomes with anemia. We specifically investigated the effect of anemia and smoking on fetal birth weight. Our study found that the mean of $\mathrm{Hb}$ was lower in the LBW group compared with the non-LBW group ( $\mathrm{p}=0.035)$. Also, the rate of smoking was found high in the LBW group. In the multivariate linear regression analysis including smoking, age, $\mathrm{BMI}$, and $\mathrm{Hb}$ levels, $\mathrm{Hb}$ was found to be a significant predictor of fetal birth weight $(B=15.469$; $\mathrm{p}=0.046$ ).

Cigarette smoke contains a large number of toxins that affect the entire body system. Naturally, they also
Table 1. Comparison of variables according to smoking status.

\begin{tabular}{|c|c|c|c|}
\hline & \multicolumn{2}{|c|}{ Smoking status } & \multirow[b]{2}{*}{ p } \\
\hline & $\begin{array}{c}\text { Yes } \\
\mathrm{n}=72\end{array}$ & $\begin{array}{c}\text { No } \\
n=1356\end{array}$ & \\
\hline Age (year) & $26.8 \pm 5.3$ & $26.3 \pm 5.5$ & .471 \\
\hline Gravida & $3(1-6)$ & $2(1-8)$ & .001 \\
\hline Parity & $1(0-4)$ & $1(0-7)$ & .009 \\
\hline Gestational week & $38.7 \pm 0.99$ & $38.9 \pm 1.06$ & .196 \\
\hline Birth weight & $2839.7 \pm 491.5$ & $3302.1 \pm 381.5$ & $<.001$ \\
\hline$\geq 2500 \mathrm{~g}$ & $54(\% 75)$ & $1340(\% 98.8)$ & $<.001$ \\
\hline$<2500 \mathrm{~g}$ & $18(\% 25)$ & $16(\% 1.2)$ & \\
\hline Height & $163.1 \pm 5.5$ & $162.9 \pm 4.2$ & .759 \\
\hline Weight & $74.1 \pm 9.5$ & $76.0 \pm 9.2$ & .092 \\
\hline BMI & $26.8 \pm 5.3$ & $26.3 \pm 5.5$ & .065 \\
\hline $\mathrm{Hgb}(\mathrm{g} / \mathrm{dL})$ & $11.8 \pm 1.5$ & $12.1 \pm 1.3$ & .059 \\
\hline Hct (\%) & $35.4 \pm 3.9$ & $36.4 \pm 3.6$ & .025 \\
\hline Anemia $(\mathrm{Hb}<11 \mathrm{~g} / \mathrm{dL})$ & $57(\% 4.9)$ & $1105(\% 95.1)$ & .326 \\
\hline Non-anemia $(\mathrm{Hb} \geq 11 \mathrm{~g} / \mathrm{dL})$ & $6(\% 3.3)$ & $178(\% 96.7)$ & \\
\hline $\mathrm{Hb}<10 \mathrm{~g} / \mathrm{dL}$ & $9(\% 12.5)$ & $73(\% 5.4)$ & .026 \\
\hline $\mathrm{Hb} \geq 10 \mathrm{~g} / \mathrm{dL},<11 \mathrm{~g} / \mathrm{dL}$ & $6(\% 8.3)$ & $178(\% 13.1)$ & \\
\hline $\mathrm{Hb} \geq 11 \mathrm{~g} / \mathrm{dL}$ & $57(\% 83.3)$ & $1105(\% 81.2)$ & \\
\hline
\end{tabular}

Data were analyzed by independent sample t-test, Mann-Whitney $U$ test, Pearson chi-square test. Data were given as mean \pm standard deviation median (min-max) or as n (\%). BMI: body mass index; Hb: hemoglobin; Hct: hematocrit.

have effects on fetal health during pregnancy. ${ }^{[10]}$ In a study by Stephanie et al., it was found that women who smoked had a lower weight by $200 \mathrm{~g}^{[20]}$ Women who smoked were 1.5 to 3.5 times more likely to have an LBW infant in other studies. ${ }^{[2,22]}$ In a study by Chuhao et al., it was found that passive smoking resulted in $\mathrm{LBW} .^{[23}$ Smoking was associated with low fetal birth weight, miscarriage, stillbirth and neonatal death, preterm premature rupture of membranes, placental abruption/placenta previa, preterm birth, congenital malformations. ${ }^{[24}$ Various mechanisms describing adverse pregnancy outcomes associated with maternal smoking have been observed. These include impaired fetal oxygenation, varying fetal development, and physiologic response, and toxin exposure. Data on mechanisms associated with ecigarette use are currently mainly available from animal models. ${ }^{[25,26]}$ In our study, lower birth weight was found in patients who smoked, similar to the literature. In addition, in our study, $\mathrm{Hb}$ and Hct levels were found lower in patients who smoked. In literature, it was reported that smoking caused increase in Hct and $\mathrm{Hb}$ levels. ${ }^{[13]}$ Although it was expected that $\mathrm{Hb}$ levels should be high- 
Table 2. Comparison of variables according to fetal birth weight categories.

\begin{tabular}{|c|c|c|c|c|c|c|}
\hline & $\begin{array}{l}\text { LBW } \\
n=34\end{array}$ & $\begin{array}{c}\text { NBW } \\
n=1341\end{array}$ & $\begin{array}{c}\text { Macro } \\
n=53\end{array}$ & $p^{*}$ & $\mathbf{p}^{\dagger}$ & $\mathbf{p}^{\ddagger}$ \\
\hline Age (year) & $26.2 \pm 6.6$ & $26.3 \pm 5.4$ & $26.4 \pm 6.5$ & .923 & .985 & \\
\hline Gravida & $2(1-6)$ & $2(1-8)$ & $2(1-6)$ & .289 & .411 & \\
\hline Parity & $0(0-4)$ & $1(0-7)$ & $1(0-5)$ & .141 & .259 & \\
\hline Weight & $74.0 \pm 10.7$ & $75.8 \pm 9.1$ & $79.3 \pm 11.1$ & .207 & .048 & $\begin{array}{l}p(a b)=.679 \\
p(a c)=.074 \\
p(b c)=.072\end{array}$ \\
\hline Height & $162.2 \pm 4.9$ & $163.0 \pm 4.3$ & $163.5 \pm 4.5$ & .311 & .426 & \\
\hline BMI & $28.1 \pm 3.5$ & $28.5 \pm 3.3$ & $29.7 \pm 3.6$ & .350 & .037 & $\begin{array}{l}p(a b)=.664 \\
p(a c)=.071 \\
p(b c)=.045\end{array}$ \\
\hline GW & $39.1 \pm 1.0$ & $38.9 \pm 1.1$ & $39.0 \pm 1.2$ & .182 & .307 & \\
\hline \multicolumn{7}{|l|}{ Smoking } \\
\hline Yes & $18(\% 52.9)$ & $53(\% 4)$ & $1(\% 1.9)$ & $<.001$ & $<.001$ & \\
\hline No & $16(\% 47.1)$ & $1288(\% 96.0)$ & $52(\% 98.1)$ & & & \\
\hline Hct (\%) & $35.2 \pm 4.5$ & $36.3 \pm 3.6$ & $36.4 \pm 3.7$ & .061 & .105 & \\
\hline $\mathrm{Hb}(\mathrm{g} / \mathrm{dL})$ & $11.6 \pm 1.7$ & $12.1 \pm 1.3$ & $12.2 \pm 1.3$ & .035 & .171 & \\
\hline Anemia $(\mathrm{Hb}<11 \mathrm{~g} / \mathrm{dL})$ & $3(\% 10.7)$ & $175(\% 13.8)$ & $6(\% 12.0)$ & .645 & .842 & \\
\hline Non-anemia $(\mathrm{Hb} \geq 11 \mathrm{~g} / \mathrm{dL})$ & $25(\% 89.3)$ & $1093(\% 86.2)$ & $44(\% 88)$ & & & \\
\hline $\mathrm{Hb}<10 \mathrm{~g} / \mathrm{dL}$ & $6(\% 17.6)$ & $73(\% 5.4)$ & $3(\% 5.7)$ & .010 & .051 & \\
\hline $\mathrm{Hb} \geq 10 \mathrm{~g} / \mathrm{dL},<11 \mathrm{~g} / \mathrm{dL}$ & $3(\% 8.8)$ & $175(\% 13.0)$ & $6(\% 11.3)$ & & & \\
\hline $\mathrm{Hb} \geq 11 \mathrm{~g} / \mathrm{dL}$ & $25(\% 73.5)$ & $1093(\% 81.5)$ & $44(\% 83)$ & & & \\
\hline
\end{tabular}

Results were analyzed using one-way ANOVA (Welch), Kruskal-Wallis test, Independent sample t-test, Mann-Whitney U test and Pearson's chi-square test. p*: between LBW and NBW groups; $\mathbf{p}^{+}$: between all groups; $\mathrm{p}^{\ddagger}$ : within groups. BMI: body mass index; GW: gestational week; Hb: hemoglobin; Hct: hematocrit; LBW: low birth weight; NBW: normal birth weight.

er in smoking women than non-smoking women, it was not found higher. The Hb level we detected in smoking women may also be high values related to smoking. New $\mathrm{Hb}$ threshold values may be required for pregnant women who smoke. However, studies conducted with pregnant women have shown that smoking does no effect on hematological changes. ${ }^{[27]}$ However, it is not possible to explain this effect only with smoking, due to the physiological changes that occur during pregnancy, the unknown frequency of smoking, the unknown blood carbon monoxide levels, and the lack of maternal nutrition and iron support that affect the hemoglobin value. In our study, in regression analysis, smoking, compared with non-smoking, negatively affected fetal birth weight.

Another factor effective in fetal weight is maternal weight status. The relationship between maternal weight status and fetal weight has been shown in many studies. ${ }^{[28,29]}$ In our study, we used maternal pre-birth weight

Table 3. Linear regression analysis of the factors to predict fetal birth weight.

\begin{tabular}{|c|c|c|c|c|c|}
\hline & B & $\beta$ & $\% 95 \mathrm{Cl}$ & $t$ & $\mathbf{p}$ \\
\hline Age (year) & -2.167 & -0.030 & $(-5.820)-(1.485)$ & -1.164 & .245 \\
\hline BMI & 16.227 & 0.134 & $(10.202)-(22.251)$ & 5.318 & $<.001$ \\
\hline Smoking (yes) & -449.135 & -0.245 & $(-535.936)-(-353.422)$ & -9.559 & $<.001$ \\
\hline $\mathrm{Hb}$ & 15.469 & 0.051 & $(0.275)-(30.663)$ & 1.997 & .046 \\
\hline Consant & 2707.137 & & $(2448.605)-(2965.668)$ & 20.541 & $<.001$ \\
\hline
\end{tabular}

Results were analyzed by multivariate linear regression. $\boldsymbol{\beta}$ : standardized coefficients; B: unstandardized coefficients; BMI: body mass index; Cl: confidence interval; Hb: hemoglobin. 
and BMI. In multivariate linear regression analysis, we found that BMI was a significant predictor of fetal birth weight.

The limitations of the study are its design being a retrospective study, the frequency and time of smoking of the patients are unknown, which type of cigarette is unknown, the blood carbon monoxide levels of the patients are unknown, and that all factors affecting weight gain were not included in the study. The strength of the study is that more specifically, smoking status and $\mathrm{Hb}$ values are investigated in terms of fetal weight.

\section{Conclusion}

Smoking at the end of the pregnancy correlates with lower birth weight. Higher BMI and higher $\mathrm{Hb}$ levels at the end of the pregnancy correlate with higher birth weight. However, prospective studies reinforced with blood and urine analysis will provide more precise results with the inclusion of the passive smoking of patients.

Funding: This work did not receive any specific grant from funding agencies in the public, commercial, or not-for-profit sectors.

Compliance with Ethical Standards: The authors stated that the standards regarding research and publication ethics, the Personal Data Protection Law and the copyright regulations applicable to intellectual and artistic works are complied with and there is no conflict of interest.

\section{References}

1. Eskes M, Waelput AJM, Scherjon SA, Bergman KA, AbuHanna A, Ravelli ACJ. Small for gestational age and perinatal mortality at term: an audit in a Dutch national cohort study. Eur J Obstet Gynecol Reprod Biol 2017;215:62-7. [PubMed] [CrossRef]

2. Kominiarek MA, Peaceman AM. Gestational weight gain. Am J Obstet Gynecol 2017;217:642-51. [PubMed] [CrossRef]

3. Jung J, Rahman MM, Rahman MS, Swe KT, Islam MR, Rahman MO, et al. Effects of hemoglobin levels during pregnancy on adverse maternal and infant outcomes: a systematic review and meta-analysis. Ann N Y Acad Sci 2019;1450:69-82. [PubMed] [CrossRef]

4. Young MF, Oaks BM, Tandon S, Martorell R, Dewey KG, Wendt AS. Maternal hemoglobin concentrations across pregnancy and maternal and child health: a systematic review and meta-analysis. Ann N Y Acad Sci 2019;1450:47-68. [PubMed] [CrossRef]

5. Pintican D, Poienar AA, Strilciuc S, Mihu D. Effects of maternal smoking on human placental vascularization: a systematic review. Taiwan J Obstet Gynecol 2019;58:454-9. [PubMed] [CrossRef]
6. Kmietowicz Z. Smoking rates among pregnant women fall to all time low of 11\%. BMJ 2015;350:h3335. [PubMed] [CrossRef]

7. Curtin SC, Matthews TJ. Smoking prevalence and cessation before and during pregnancy: data from the birth certificate, 2014. Natl Vital Stat Rep 2016;65:1-14. [PubMed]

8. Marakoğlu K, Erdem D. Attitudes and behaviors of pregnant women about smoking in Konya. [Article in Turkish] Erciyes Medical Journal 2007;29:47-55.

9. Spencer K, Cowans NJ. Accuracy of self-reported smoking status in first trimester aneuploidy screening. Prenat Diagn 2013;33:245-50. [PubMed] [CrossRef]

10. Tong VT, Dietz PM, Morrow B, D'Angelo DV, Farr SL, Rockhill KM, et al.; Centers for Disease Control and Prevention (CDC). Trends in smoking before, during, and after pregnancy - Pregnancy Risk Assessment Monitoring System, United States, 40 sites, 2000-2010. MMWR Surveill Summ 2013;62:1-19. [PubMed]

11. Stevens GA, Finucane MM, De-Regil LM, Paciorek CJ, Flaxman SR, Branca F, et al.; Nutrition Impact Model Study Group (Anaemia). Global, regional, and national trends in haemoglobin concentration and prevalence of total and severe anaemia in children and pregnant and non-pregnant women for 1995-2011: a systematic analysis of population-representative data. Lancet Glob Health 2013;1:e16-25. [PubMed] [CrossRef]

12. Karaşahin E, Ceyhan ST, Göktolga Ü, Keskin U, Başer İ. Maternal anemia and perinatal outcome. Perinatal Journal 2007;15:127-30.

13. Pedersen KM, Çolak Y, Ellervik C, Hasselbalch HC, Bojesen SE, Nordestgaard BG. Smoking and increased white and red blood cells. Arterioscler Thromb Vasc Biol 2019;39: 965-77. [PubMed] [CrossRef]

14. Watkins VY, Frolova AI, Stout MJ, Carter EB, Macones GA, Cahill AG, et al. The relationship between maternal anemia and umbilical cord oxygen content at delivery. Am J Obstet Gynecol MFM 2021;3:100270. [PubMed] [CrossRef]

15. WHO. Global anaemia reduction efforts among women of reproductive age: impact, achievement of targets and the way forward for optimizing efforts. Geneva: WHO; 2020. Retrieved from https://www.who.int/publications/i/item/ 9789240012202

16. Whittaker PG, Macphail S, Lind T. Serial hematologic changes and pregnancy outcome. Obstet Gynecol 1996;88: 33-9. [PubMed] [CrossRef]

17. American College of Obstetricians and Gynecologists. ACOG Practice Bulletin No. 95: anemia in pregnancy. Obstet Gynecol 2008;112:201-7. [PubMed] [CrossRef]

18. Daru J, Zamora J, Fernández-Félix BM, Vogel J, Oladapo OT, Morisaki N, et al. Risk of maternal mortality in women with severe anaemia during pregnancy and post partum: a multilevel analysis. Lancet Glob Health 2018;6:e548-e54. [PubMed] [CrossRef]

19. Tunkyi K, Moodley J. Anemia and pregnancy outcomes: a longitudinal study. J Matern Fetal Neonatal Med 2018;31: 2594-8. [PubMed] [CrossRef] 
20. Witt SH, Frank J, Gilles M, Lang M, Treutlein J, Streit F, et al. Impact on birth weight of maternal smoking throughout pregnancy mediated by DNA methylation. BMC Genomics 2018;19:290. [PubMed] [CrossRef]

21. Alameda County Low Birth Weight Study Group. Cigarette smoking and the risk of low birth weight: a comparison in black and white women. Epidemiology 1990;1:201-5. [PubMed]

22. Lieberman E, Gremy I, Lang JM, Cohen AP. Low birthweight at term and the timing of fetal exposure to maternal smoking. Am J Public Health 1994;84:1127-31. [PubMed] [CrossRef]

23. Xi C, Luo M, Wang T, Wang Y, Wang S, Guo L, et al. Association between maternal lifestyle factors and low birth weight in preterm and term births: a case-control study. Reprod Health 2020;17:93. [PubMed] [CrossRef]

24. Tobacco and nicotine cessation during pregnancy: ACOG Committee Opinion, Number 807. Obstet Gynecol 2020;135: e221-9. [PubMed] [CrossRef]

25. Shao XM, López-Valdés HE, Liang J, Feldman JL. Inhaled nicotine equivalent to cigarette smoking disrupts systemic and uterine hemodynamics and induces cardiac arrhythmia in pregnant rats. Sci Rep 2017;7:16974. [PubMed] [CrossRef]

26. Chen H, Li G, Chan YL, Chapman DG, Sukjamnong S, Nguyen $\mathrm{T}$, et al. Maternal e-cigarette exposure in mice alters DNA methylation and lung cytokine expression in offspring. Am J Respir Cell Mol Biol 2018;58:366-77. [PubMed] [CrossRef]

27. Wojtyła C, Głuszek Ł, Biliński P, Paprzycki P, Warzocha K. Smoking during pregnancy - hematological observations in pregnant women and their newborns after delivery. Ann Agric Environ Med 2012;19:836-41. [PubMed]

28. Ferraro ZM, Barrowman N, Prud'homme D, Walker M, Wen SW, Rodger M, et al. Excessive gestational weight gain predicts large for gestational age neonates independent of maternal body mass index. J Matern Fetal Neonatal Med 2012;25:538-42. [PubMed] [CrossRef]

29. Goldstein RF, Abell SK, Ranasinha S, Misso M, Boyle JA, Black $\mathrm{MH}$, et al. Association of gestational weight gain with maternal and infant outcomes: a systematic review and metaanalysis. JAMA 2017;317:2207-25. [PubMed] [CrossRef]

This work is licensed under the Creative Commons Attribution-NonCommercial-NoDerivs 4.0 Unported (CC BY-NC-ND4.0) License. To view a copy of this license, visit http://creativecommons.org/licenses/by-nc-nd/4.0/ or send a letter to Creative Commons, PO Box 1866, Mountain View, CA 94042 , USA.

Publisher's Note: The content of this publication does not necessarily reflect the views or policies of the publisher, nor does any mention of trade names, commercial products, of organizations imply endorsement by the publisher. Scientific and legal responsibilities of published manuscript belong to their author(s). The publisher remains neutral with regard to jurisdictional claims in published maps and institutional affiliations. 